\title{
ABrief Review of Scholarly Events in the Field of Legal History in Ukraine in 2020
}

Keywords: Ukraine, European integration, legal history, legal regulation, International Association of Legal Historians

Słowa kluczowe: Ukraina, integracja europejska, historia prawa, regulacje prawne, Międzynarodowe Stowarzyszenie Historyków Prawa

During 2020 one historical legal conference was held and several monographs in the field of Legal History were published in Ukraine.

\section{Monographs}

Ukraine on the Way to European Integration: Historical and Legal Insight (in Ukrainian: Україна на шляху до європейської інтеграції: історико-правовий екскурс) by Minas Arakelian. ${ }^{1}$ The monograph combines theoretical and historical-legal materials, covering the period from the times of the Ukrainian Hetmanate to the present chronologically. The paper examines the European integration processes which took place in Ukraine at different historical stages, and considers Ukraine as a primordial part of the greater European territory with common cultural values and a common past. The monograph analyzes in particular, the pro-European vector of the development of the Ukrainian Hetmanate and its influence on the formation of Ukrainian constitutionalism. The development of Ukrainian statehood in the early $19^{\text {th }}$ century under integration processes prevalent in Europe, and the integration processes of Soviet Ukraine with the countries of Central and Eastern Ukraine in 1919-1991 are also featured. Moreover, the paper de-

${ }^{1}$ Arakelian, Minas. Ukraina na shliakhu do yevropeiskoi intehratsii: istoryko-pravovyi ekskurs. Kyiv: Feniks, 2020, 248 p. 
scribes historical and legal characteristics of the relations between Ukraine and the EU during the period 1991-2016.

State and Legal Policy of the "Founding Fathers" of the United States (in Ukrainian: Державно-правова політика “батьків-засновників" США) by Viktor Kalashnykov. ${ }^{2}$ The peculiarities of the formation of the legal policy and state in the US are described, being the result of law-making and law implementation activities of the "founding fathers" of the young American state. The legal views of George Washington, Alexander Hamilton, John Jay, James Madison, Thomas Jefferson, and Benjamin Franklin on the legal consolidation of the foundations of external, military, naval, monetary, customs, criminal, slavery, and Indian policies were presented.

Local Judicial Institutions, Advocacy, and Notary in the System of Occupation Apparatus under the Reich Commissariat "Ukraine" and the Military Zone of Occupation (1941-1944): Social-Legal Dimensions (in Ukrainian: Місцеві судові установи, адвокатура та нотаріат у системі окупаційного апарату влади Райхскомісаріату "Україна" та військової зони окупації (1941-1944рр.): соціально-правові виміри) by Alina Ivanenko. ${ }^{3}$ The book is devoted to the study of the German occupation policy that was in force on the territory of the Reich Commissariat "Ukraine" and the military zone in the period 1941-1944. The work is based on the analysis of original archival sources, most of which have already been introduced into academic circulation. Based on systematic analysis of a wide range of archival sources, published documents, and domestic and foreign academic literature, a comprehensive study of the functioning of judicial institutions, and advocacy and notary functions in the CCU and WHO in the 1941-1944 time frame has been carried out for the first time. Significant attention is paid to the study of the functioning of courts, and advocacy and notary functions as one of the attempts of the occupation administration to regulate legal interaction among the local populace.

Department of Criminology: History of Formation and Development. To the $80^{\text {th }}$ Anniversary of Its Foundation (in Ukrainian: Кафедра криміналістики: історія становлення та розвитку. До 80-річчя заснування) by Valeriy Shepitko and Viktoriia Aleksiichuk. ${ }^{4}$ The work includes research into the history of the formation and development of the Department of Criminology of the Yaroslav Mudruy National Law University. The work presents information on laboratories and divisions of the department, along with features of teaching activities. The reference data on outstanding professors and employees of the department are systematized, and the information on executed and defended dissertations is generalized. Data on academic events with the participation of department representatives, their academic, educational, and educational-methodical works are indicated.

\footnotetext{
2 Kalashnykov, Viktor. Derzhavno-pravova polityka "batkiv-zasnovnykiv" SShA. Dnipro: RWW DNU, 2020, 200 pp.

${ }^{3}$ Ivanenko, Alina. Mistsevi sudovi ustanovy, advokatura ta notariat u systemi okupatsiinoho aparatu vlady Raikhskomisariatu "Ukraina" ta viiskovoi zony okupatsii (1941-1944 rr.): sotsialno-pravovi vymiry. Chernihiv: PAT PWK Desna, 2020, 485 pp.

${ }^{4}$ Aleksiichuk, Viktoriia. Kafedra kryminalistyky: istoriia stanovlennia ta rozvytku. Do 80-richchia zasnuvannia. Kharkiv: Prawo, 2020, 276 pp.
} 


\section{Conference}

On December 22 2 nd 2020 the International Conference "The Organization of Legal Science and Education in Ukraine and The World: Historical Experience, Modernity, and Perspective" was held. This conference was organized by the International Association of Law Historians. The following topics were discussed at the conference: Academician Yu. S. Shemshuchenko: creative paths and achievements in the field of service to science; Ukrainian legal science: institutional and anthropological dimensions; Legal doctrine as the basis of legal education; Historical forms of organization of academic and educational processes in the legal sphere; Academic and university legal disciplines and legal education: questions, organization, and interaction; National academic societies and educational systems in the context of globalization; Reform of legal education in Ukraine: challenges and prospects; Academic legal expertise and other issues of the legal support of practical activities. 